\title{
AEROPALYNOLOGICAL ASPECTS IN THE DETECTION OF THE QUALITY OF AIR IN BRATISLAVA
}

\author{
JOZEF DUŠIČKA ${ }^{1}$, KAROL MIČIETA ${ }^{1}$, EVA BRUTOVSKÁ ${ }^{1}$, ANDREA SÁMELOVÁ ${ }^{1}$, \\ JANA ŠČEVKOVÁ ${ }^{1}$, MÁRIA ZÁMEČNÍKOVÁ ${ }^{2}$, ALENA TERENOVÁ ${ }^{2}$ \\ ${ }^{1}$ Faculty of Natural Sciences, Department of Botany, Comenius University, Bratislava, Slovak Republic; \\ e-mail: dusicka@fns.uniba.sk \\ ${ }^{2}$ Public Health Authority, Bratislava, Slovak Republic
}

\begin{abstract}
Dušička J., Mičieta K., Brutovská E., Sámelová A., Ščevková J., Zámečníková M., Terenová A.: Aeropalynological aspects in the detection of the quality of air in Bratislava. Ekológia (Bratislava), Vol. 32, No. 1, p. 39-53, 2013.

This work is focused on mapping the aeropalynologic situation in the Bratislavan atmosphere. Volumetric pollen and pollen abortivity analyses were used for this purpose. The research comprised comparison of two pollen stations in this city between 2007 and 2011. Twice the number of pollen grains was measured at the U.V.Z. station compared to the D.B. station. Results showed that (1) the highest pollen totals for the period were recorded in the Urticaceae family, (2) April was the month with the highest pollen yield, and (3) species of the Urticaceae family had the longest pollen season of all studied taxa. The detected differences may have been due to various factors including; the very different habitats in the vicinity of the stations, slightly different climatic conditions, different evaluation methods and human factors. The ecogenotoxicity and mutagenicity of air at these selected city locations was evaluated and compared, and the effectiveness of our methods were verified by Betula pendula $\mathrm{R}$ o $\mathrm{th}$. and Pinus sylvestris $\mathrm{L}$. indicator species.
\end{abstract}

Key words: aeropalynology, pollen, abortivity, allergy, ecogenotoxicity.

\section{Introduction}

Different anthropogenic activities and their heterogeneous xenobiotic products negatively influence individual parts of the landscape and enter the cycle of matter and energy in the natural environment. These xenobiotic products (ecotoxic factors) are transformed by their interactions with the environment and their mutual interactions, and consecutively influence the environment in their changed form (Bromberg, 1990). Therefore, precise and regular bio-monitoring is necessary in order to evaluate their toxic influence on individual parts of the environment.

The high sensitivity of pollen grains enables their use as a basic model for indicating phytotoxicity and mutagenicity (Mičieta, Murín, 1996) and their abortion due to environmental pollution can synergize allergenic potential in the population (Horak, Jäger, 1993, ex Hrubiško, 1996). Therefore, it was decided to compare the aeropalynologic research of two pollen stations in Bratislava during 2007-2011, and to evaluate the quantitative presence of 
abortive pollen grains in the air of Bratislava, focusing on the species Betula pendula Roth. and Pinus sylvestris L.

Two pollen monitoring station are currently operating in different parts of the city of Bratislava; the Department of Botany of the Comenius University (D.B) and The Public Health Office of the Slovak Republic (Úrad verejného zdravotníctva - U.V.Z). Since the number of people suffering pollen allergies (pollinoses) increases annually, the quantitative and qualitative analysis of pollen grains in densely populated areas is very important and necessary (D'Amato et al., 2007). Pollen grains, pollen mother cells and pollen tetrades of diploid species can be effectively used as basic bio-indication material to detect ecogenotoxic deterioration of the environment (Mičieta, Murín, 1996).

The goal of our study is to present and compare the results of aeropalynological monitoring carried out by standardized volumetric methodology which will also detect the incidence of abortive pollen grains in the air of Bratislava. We also emphasize the need to monitor the arguable increase of the allergenic potential of pollen to cause pollinoses induced by increased frequency of altered pollen in the environment.

\section{Material and methods}

The study was carried out in Bratislava, the capital of Slovakia (Fig. 1). Bratislava lies on the range of the Danube plain, the Malé Karpaty Mt. and the Záhorská nížina plain. It mainly covers the alluvial deposits of the Danube, which are considerably utilized as urbanized areas, industrial complexes, and partly used for agriculture. Influenced by intense human activity, the original vegetation cover was completely removed or largely modified. Original plant communities were replaced by semi-natural or synanthropic ones. Anthropogenic degradation of soils changed the soil-ecological properties, so that Bratislava's urban vegetation is mainly represented by ornamental park vegetation and vegetation along foothpaths and roads. Trees are mainly represented by the species; Pinus spp., Acer spp., Populus spp., Betula pendula, Fraxinus spp., Tilia cordata, Ulmus spp., Quercus spp. and Castanea spp. Weed species are mainly from the Poaceae and Chenopodiaceae families, with Plantago spp., Ambrosia spp., Artemisia spp. and Urtica spp. A considerable portion of the Bratislavan vegetation consists of gardens close to houses; for example, Prunus spp., Malus spp. and the Asteraceae family. The natural vegetation of Bratislava and its surrounds particularly con-

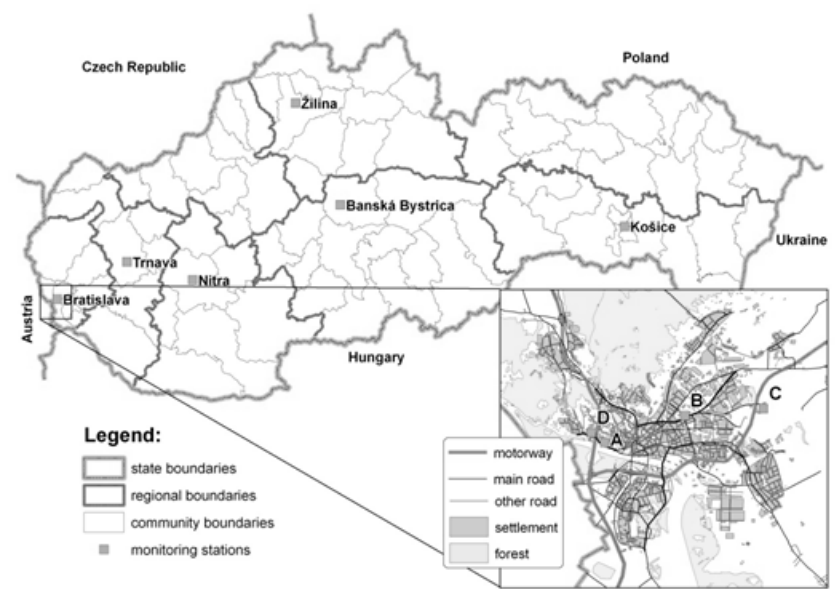

Fig. 1. Geographical localisation of pollen monitoring stations (A - D.B., B - U.V.Z.) and meteorological observatories (C - Airport, D - Mlynská dolina). 
sists of willow-poplar alluvial forests and lowland wetlands. Many authors have studied the vegetation of Bratislava, including; Jurko (1958); Mucina (1981); Eliáš (1985, 1989); Jarolímek (1985, 1994); Michalko et al. (1986); Drábová-Kochjarová (1990); Zlinská (1996); Feráková (1996, 1997) and Daubnerová (1999).

The mean annual air temperature in Bratislava is $10.6^{\circ} \mathrm{C}$, with $-1.6^{\circ} \mathrm{C}$ in the coldest month of the year, January, and $20.5^{\circ} \mathrm{C}$ in the warmest month, July. The annual precipitation ranges between 530 and $650 \mathrm{~mm}$, and annual sunshine approximates 966 hours.

The first part of the study compares data obtained from the following pollen monitoring stations; (1) the pollen trap on the roof of D.B. which is in the north-western part of the city, 10 metres above ground $\left(48^{\circ} 08^{`} \mathrm{~N}, 17^{\circ} 04^{`} \mathrm{E}\right.$, $183 \mathrm{~m}$ a.s.l.), and (2) from the pollen trap located on the roof of the U.V.Z. SR, which is in the in the eastern part of the city, 15 metres a.s.l. ( $48^{\circ} 09^{\prime} \mathrm{N}, 17^{\circ} 08^{\prime} \mathrm{E}, 172 \mathrm{~m}$ a.s.l.) (Fig. 1). These localities are $5.3 \mathrm{~km}$ apart.

The daily mean pollen concentrations were monitored from February to October over four vegetation periods (2007-2011) using a Burkard 7-day volumetric pollen trap. This sampler recorded pollen concentrations in 2-hour samples, and the obtained values were converted to daily mean pollen concentrations for analysis.

The 12-traverse transect method was employed to count the pollen grains in daily samples at the D.B. pollen station and four longitudinal transects were used at U.V.S SR. Pollen concentrations were expressed as the number of pollen grains per $1 \mathrm{~m}^{3}$ of air, and the pollen grains were identified according to Erdtman (1969), Fassatiová (1979), Spieksma et al. (1996) and Winkler et al. (2001).

The main pollen season (MPS) of selected pollen types was established by the Nilsson, Persson (1981) method which defines the main pollen season as commencing when the sum of the pollen type concentrations reaches $5 \%$ of the annual total pollen, and finishing when it reaches $95 \%$.

Birch trees are the source of one of Bratislava's most important pollen allergens, and since some of these trees grow close to the Department of Botany (D.B), evaluation focused on abortive pollen trapped during 2009, 2010 and 2011. Simultaneously, abortivity of birch pollen was noted directly in catkins growing near this trap. Although birch is not one of the recommended trees suitable for bioindication of phytotoxicity and genotoxicity (Mičieta, 1997), it was monitored and results compared because of its high spontaneous abortivity, which exceeds $5 \%$. Abortive pollen grains were determined from the trap preparations and the preparations made according to standardized procedures by Mičieta, Murín (1996). Pollen grains were isolated from anthers in catkins, dyed with $1 \%$ aniline blue in laktofenol and evaluated microscopically.

In the final part of the study we highlighted the process of valorisation of the model Pinus in biondication of environmental mutagenesis. Pinus sylvestris L. was chosen for this validation because of its abundance in areas significantly exposed to different pollution factors. These trees are often planted in city parks or near roads and subsequently exposed to high concentrations of harmful substances. Monitoring the phytotoxicity and mutagenicity, collection of pollen and fixation and evaluation were conducted using published procedures of Mičieta, Murín (1996, 1998). Indication of ecogenotoxicity and subsequent determination of the induction index - the measure of increase of ecogenotoxic deterioration and impacts on biodiversity in the urban area of Bratislava were accomplished using the procedure of Mičieta, Kunová (2000) and Mišík et al. (2007).

\section{Results}

During the five monitored years (2007-2011), a total of 426752 pollen grains were measured in the air of Bratislava, 287,959 grains were measured at the U.V.Z. station and 138,793 at D.B. (Table 1). There were no significant differences noted between the monitoring stations in this species spectrum. Only a few plants from the total 32 taxa of higher plants were absent from this monitoring of 21 trees and/or shrubs and 11 herbaceous species. Those missing specifically included pollen grains of the Cyperaceae family at the U.V.Z. station and the Ailanthus genus at D.B. (Table 2).

In quantitative terms, large differences were noted between these stations, and also at each station in individual years. The highest annual total of 74,806 pollen grains was measured at the U.V.Z station in 2011 and the lowest figure of 35,995 in 2007. Meanwhile, the D.B. station returned 38,874 as its highest pollen total in 2007 , and its lowest was the 14,475 recorded in 2008 (Table 2). 
The largest difference in pollen quantity recorded at the stations mainly involved trees. The amount of Fraxinus, Populus and Quercus taxa pollen was several times higher at the U.V.Z. station than at D.B. The opposite situation, in terms of trees, was registered for the, Juglans and Tilia taxa which provided a higher total quantity of pollen at the D.B. station than at U.V.Z. The largest difference in herbaceous taxa was observed in the genus Ambrosia and Urticaceae families, with significantly higher levels of pollen measured at the U.V.Z. station compared to D.B. (Table 1).

T a b l e 1. Pollen grain sums of the individual taxa measured at two monitoring stations (U.V.Z., D.B.) during five years (2007-2011).

\begin{tabular}{|c|c|c|c|}
\hline $\begin{array}{l}\text { Pollen taxa } \\
\text { total }\end{array}$ & $\begin{array}{l}\text { U.V.Z. } \\
\text { total }\end{array}$ & $\begin{array}{l}\text { D.B. } \\
\text { total }\end{array}$ & $\%$ for Bratislava \\
\hline Acer & 3748 & 1871 & 1.32 \\
\hline Aesculus & 297 & 730 & 0.24 \\
\hline Ailanthus & 254 & 0 & 0.06 \\
\hline Alnus & 8214 & 4442 & 2.97 \\
\hline Ambrosia & 19441 & 5812 & 5.92 \\
\hline Apiaceae & 264 & 52 & 0.07 \\
\hline Artemisia & 7123 & 4261 & 2.67 \\
\hline Asteraceae & 348 & 221 & 0.13 \\
\hline Betula & 34199 & 30041 & 15.05 \\
\hline Carpinus & 5585 & 4268 & 2.31 \\
\hline Castanea & 503 & 212 & 0.17 \\
\hline Chenopodiaceae/Amaranthaceae & 4401 & 2200 & 1.55 \\
\hline Corylus & 3396 & 2746 & 1.44 \\
\hline Cyperaceae & 0 & 606 & 0.14 \\
\hline Fagus & 3541 & 1315 & 1.14 \\
\hline Fraxinus & 17018 & 2316 & 4.53 \\
\hline Humulus & 1146 & 70 & 0.28 \\
\hline Juglans & 2034 & 2483 & 1.06 \\
\hline Larix & 32 & 41 & 0.02 \\
\hline Pinaceae & 22041 & 12734 & 8.15 \\
\hline Plantago & 5506 & 2610 & 1.90 \\
\hline Platanus & 1249 & 154 & 0.33 \\
\hline Poaceae & 17353 & 8469 & 6.05 \\
\hline Populus & 27533 & 4553 & 7.52 \\
\hline Quercus & 17224 & 2056 & 4.52 \\
\hline Rumex & 1487 & 819 & 0.54 \\
\hline Salix & 4499 & 1370 & 1.38 \\
\hline Sambucus & 2356 & 1874 & 0.99 \\
\hline Taxaceae/Cupressaceae & 19800 & 19104 & 9.12 \\
\hline Tilia & 484 & 859 & 0.31 \\
\hline Ulmus & 1606 & 650 & 0.53 \\
\hline Urticaceae & 55277 & 19854 & 17.61 \\
\hline Total & 287959 & 138793 & 100 \\
\hline$\%$ for Bratislava & 67.48 & 32.52 & \\
\hline
\end{tabular}




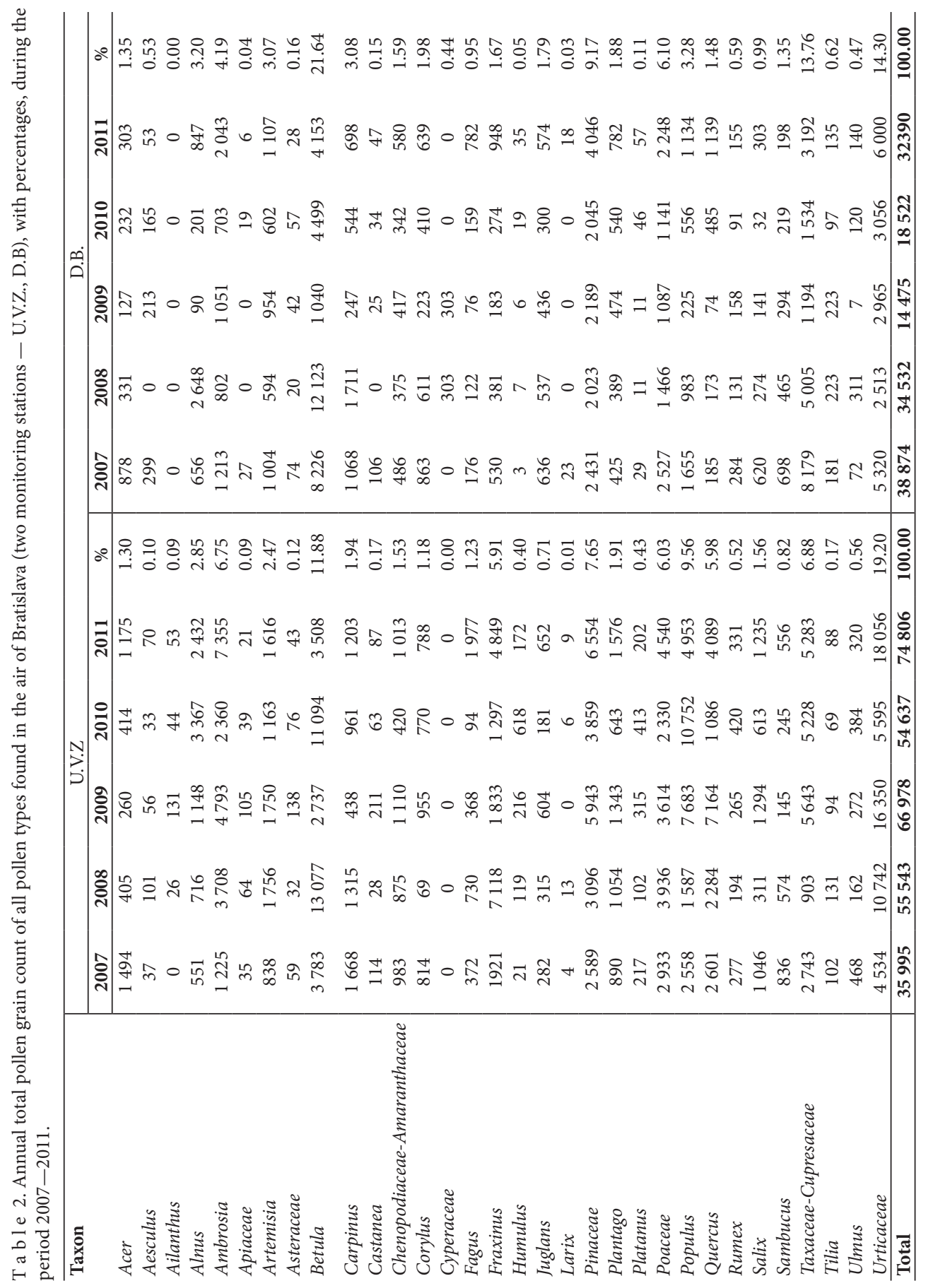



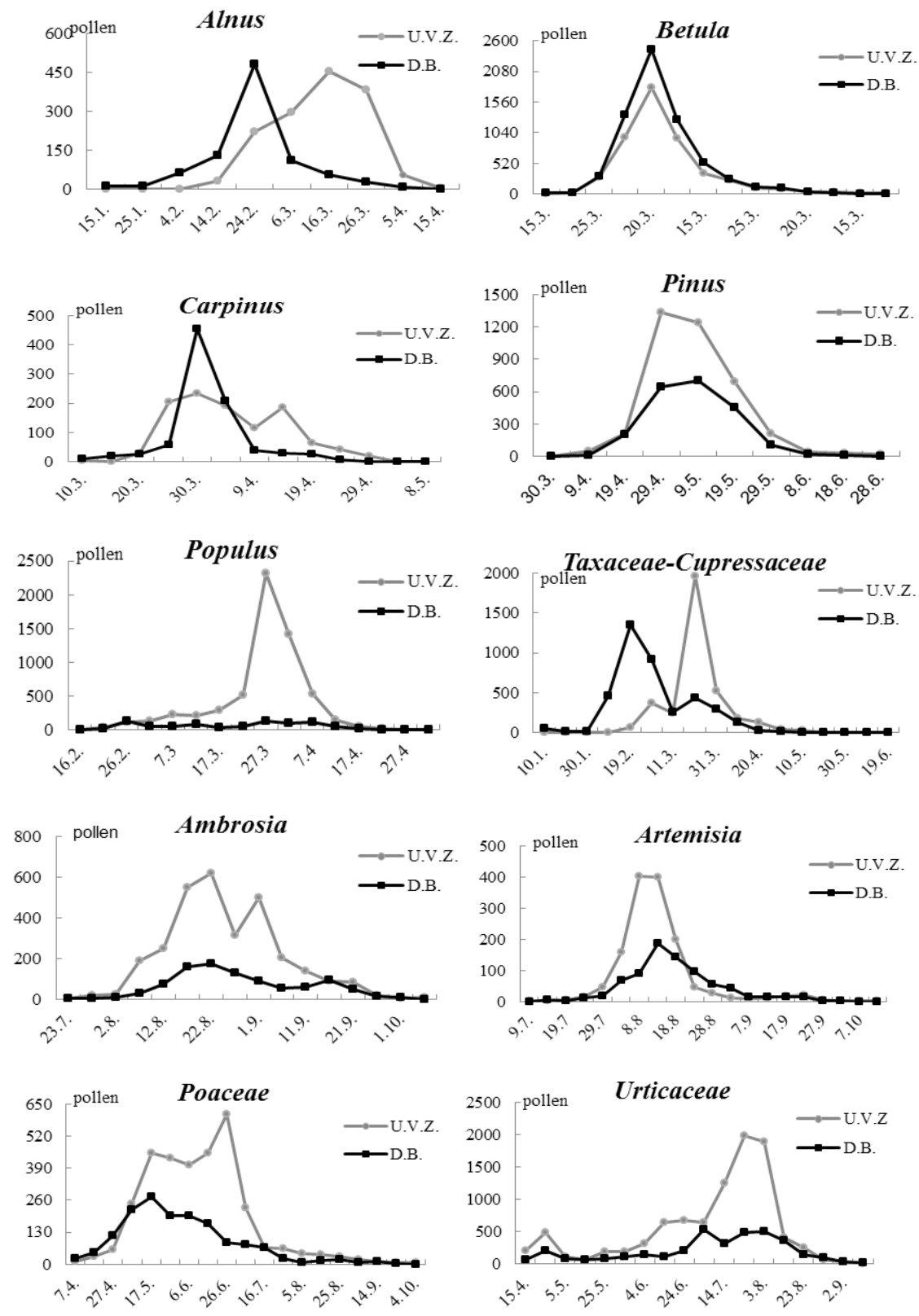

Fig. 2. Pollen calendar for the 10 pollen types collected in the Bratislava atmosphere and related 10-day means of the daily mean pollen concentrations. 
Our main focus concentrated on pollen grains from Bratislavan plant species which produced the strongest pollen allergens (Hrubiško, 1996), and which were most abundant in this period in the spectrum of the two stations. These recorded over $2 \%$ of the total pollen grains, and species involved are graphically illustrated in the pollen calendars in Figure 2. These comprised the following 10 taxa: Alnus, Betula, Carpinus, Taxaceae, Cupressaceae, Pinus and Populus in trees and/or shrubs, and Ambrosia, Artemisia, Poaceae and Urticaceae in the herbaceous species.

The highest monthly pollen total in Bratislavan air throughout the monitored period occurred in April, when the average of the two stations was 13,508. The most significant contributors to this pollen count were trees; with birch, poplar, oak, ash and hornbeam species being most prominent. April was clearly the most abundant month in each referenced year at both stations. There was one exception to this, where March dominated significantly at U.V.Z. in 2010.

Apart from this highest recording for April, all other monthly totals differed at the two stations. The month with the second highest pollen total at U.V.Z. station was August, with stinging nettle, ragweed and wormwood pollen grains predominating, while at D.B. this occurred in May, when the main contributors were pine and grasses. The month with the third highest pollen total at U.V.Z. station was March; again involving woody plants, but their presence was more variable depending on the beginning of the pollen season. This mainly depended on the length of the winter and cold days and the installation of the pollen trap. At the D.B. station it was August. The month with the lowest pollen total at both stations was October, when the pollen season ends in Slovakia and pollen grains appear only sporadically. Overall in Bratislava, the order of months in 2007-2011 with the highest pollen amounts in descending order was April, August and March,, as depicted in Table 3.

$\mathrm{T} \mathrm{a} \mathrm{b} \mathrm{le} \mathrm{3.} \mathrm{Monthly} \mathrm{sums} \mathrm{of} \mathrm{pollen} \mathrm{grains} \mathrm{in} \mathrm{the} \mathrm{air} \mathrm{of} \mathrm{Bratislava} \mathrm{(two} \mathrm{monitoring} \mathrm{stations} \mathrm{-} \mathrm{U.V.Z.,} \mathrm{D.B.)} \mathrm{in} \mathrm{years}$ 2007-2011.

\begin{tabular}{|c|c|c|c|c|c|c|c|c|c|}
\hline U.V.Z. & February & March & April & May & June & July & August & September & October \\
\hline 2007 & 800 & 7734 & 12898 & 4935 & 2525 & 2092 & 3444 & 1055 & 75 \\
\hline 2008 & 946 & 9625 & 17033 & 7032 & 3756 & 4555 & 8855 & 3101 & 29 \\
\hline 2009 & 0 & 6654 & 24236 & 8077 & 3471 & 5434 & 15649 & 1967 & 64 \\
\hline 2010 & 598 & 20715 & 14256 & 4895 & 2452 & 2669 & 6442 & 1216 & 33 \\
\hline 2011 & 4 & 4149 & 19138 & 9601 & 5475 & 5594 & 16572 & 3895 & 62 \\
\hline Average & 470 & 9775 & 17512 & 6908 & 3536 & 4069 & 10192 & 2247 & 53 \\
\hline D.B. & February & March & April & May & June & July & August & September & October \\
\hline 2007 & 4480 & 6031 & 13836 & 4582 & 1672 & 2234 & 4296 & 898 & 31 \\
\hline 2008 & 7183 & 4246 & 14157 & 3453 & 1191 & 1011 & 2204 & 776 & 30 \\
\hline 2009 & 0 & 895 & 3787 & 3122 & 1156 & 1289 & 2941 & 950 & 32 \\
\hline 2010 & 0 & 2904 & 6255 & 2894 & 1271 & 1501 & 2285 & 924 & 51 \\
\hline 2011 & 0 & 781 & 9484 & 5738 & 519 & 513 & 5042 & 1053 & 24 \\
\hline Average & 2333 & 2971 & 9504 & 3958 & 1162 & 1310 & 3354 & 920 & 34 \\
\hline $\begin{array}{l}\text { Bratislava } \\
\text { Average }\end{array}$ & 1402 & 6373 & 13508 & 5433 & 2349 & 2690 & 6773 & 1584 & 44 \\
\hline
\end{tabular}


From 2009 to 2011, evaluation of abortive birch pollen trapped at the D.B. station was the centre of focus. In addition to the standard volumetric analysis of pollen and its treatment, the abortive pollen grains and their proportion of the total amount of trapped pollen were also examined.

A total concentration of 1,040 birch pollen per $\mathrm{m}^{3}$ of air was recorded in Bratislava in 2009. The birch pollen season began on April $7^{\text {th }}$ that year and lasted until May $3^{\text {rd }}$, which accounted for 27 days. The maximum concentration of birch pollen was recorded on $8^{\text {th }}$ April, when it reached 81 grains, and 27 pollen grains from the total number of birch pollen were classified as abortive (3.27\% of the total) (Fig. 3). The highest numbers of 7 and 6 abortive pollen grains in $1 \mathrm{~m}^{3}$ of air per day was recorded on April $17^{\text {th }}$ and $22^{\text {nd }}$, respectively.

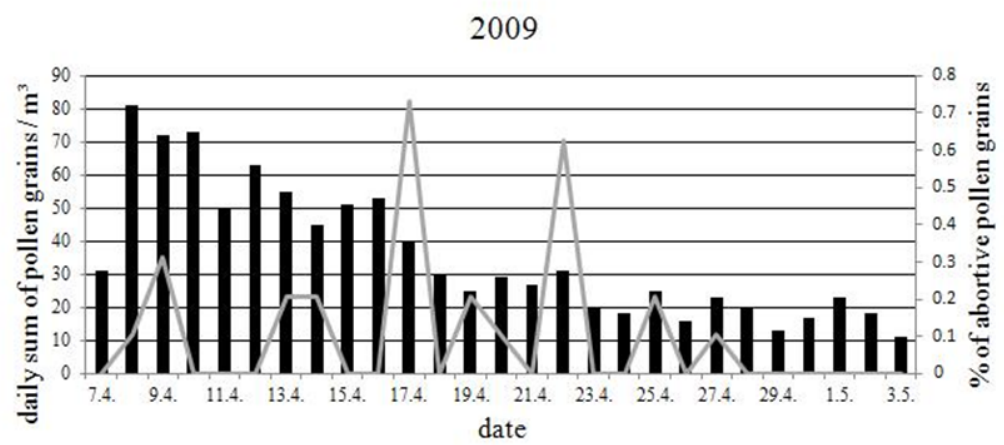

daily concentration of pollen grains

- concentration of abortive pollen grains

Fig. 3. Daily concentrations of birch pollen grains compared with the percentage of abortive pollen grains per $\mathrm{m}^{3}$ of air in 2009.

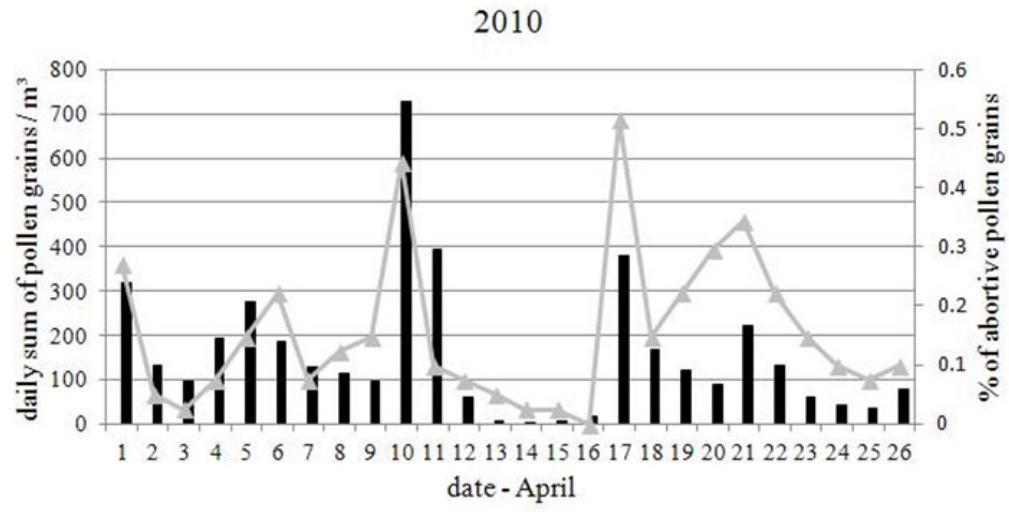

daily concentration of pollen grains

- concentration of abortive pollen grains

Fig. 4. Daily concentrations of birch pollen grains compared with the percentage of abortive pollen grains per $\mathrm{m}^{3}$ of air in 2010. 
2011

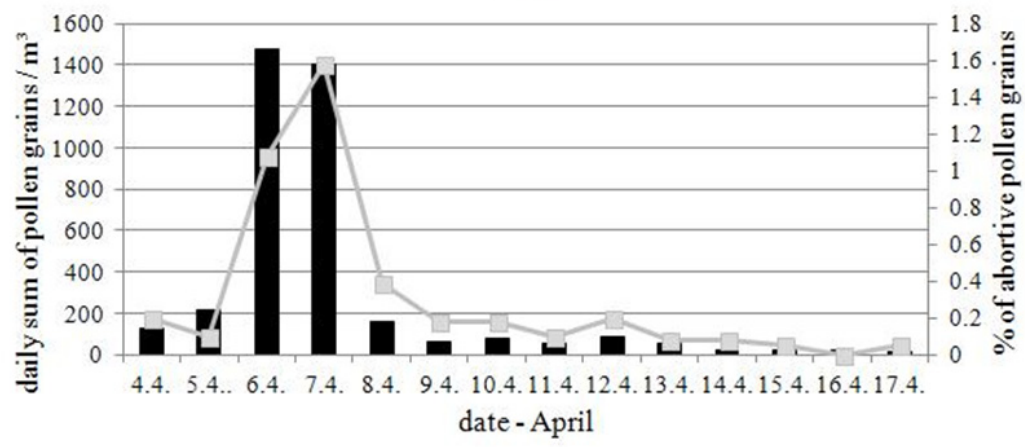

daily concentrations of pollen grains

- -concentration of abortive pollen grains

Fig. 5. Daily concentrations of birch pollen grains compared with the percentage of abortive pollen grains per $\mathrm{m}^{3}$ of air in 2011.

A much higher total concentration of 4,499 birch pollen per $\mathrm{m}^{3}$ of air was noted in 2010 . The birch pollen season started on March $31^{\text {st }}$ that year and lasted until April $25^{\text {th }}$ - a total of 26 days. The maximum daily concentration was recorded on April $9^{\text {th }}$ with 727 pollen grains, and 163 pollen grains from the total number were abortive (3.62\% of the total) (Fig. 4$)$. The highest number of 21 abortive pollen grains in $1 \mathrm{~m}^{3}$ of air was recorded on April $16^{\text {th }}$.

The year 2011 was special, as the birch pollen season lasted only 14 days that year- approximately half the two preceding years. It started on April $4^{\text {th }}$ and ended on April $17^{\text {th }}$. The annual amount of pollen per $\mathrm{m}^{3}$ of air was 4,152 and the maximum daily concentration of 1,478 grains was measured on April $6^{\text {th }}$. There were 156 abortive pollen grains, at $3.52 \%$ of the annual total. Of these, 58 were recorded on April $7^{\text {th }}$ (Fig. 5).

Research into pollen grain abortivity collected directly from the anther catkins of individuals growing in close proximity to the Botany Department was performed in 2009-2011 and results are recorded in Table 4.

The observed values of pollen abortivity from the pollen trap and from individual catkins are compared in the Fig. 6.

The final part of this work involved evaluation of the pollen abortivity of Pinus sylvestris L. in various Bratislavan locations in 2009-2011 (Table 5). Here, potential pollution was presumed to be due to transport and industrial emissions. Simultaneously, induction factors were determined for these localities over this 3 year period. This was achieved by comparing the percentage of abortive pollen grains at the polluted site with that at the control site (Fig. 7).

The highest abortivity values of pollen species compared to the reference sample was recorded at the Bratislavan Istrochem locality in 2010. This value was almost four times higher than the reference sample value. On average, the lowest values of the monitored sites were measured in the Bratislavan suburb of Rača. Induction ecogenotoxicity factors in different 
$\mathrm{T}$ a b l e 4. Abortivity of birch pollen grains from the aglets of individuals growing in proximity of the Department of Botany during the years 2009-2011.

\begin{tabular}{ccc}
\hline Year & Number of evaluated pollen grains & Abortivity in \% \\
\hline 2009 & 1000 & $4.2 \pm 0.3$ \\
2010 & 1000 & $5.9 \pm 0.6$ \\
2011 & 1000 & $4.7 \pm 0.2$ \\
\hline
\end{tabular}

T a b le 5. Pollen abortivity of Pinus sylvestris at sampling sites in Bratislava during the years 2009—2011.

\begin{tabular}{|c|c|c|c|}
\hline \multicolumn{4}{|c|}{ Abortivity in \% } \\
\hline Locality & 2009 & 2010 & 2011 \\
\hline City incinerator & 6.4 & 7.1 & 7.2 \\
\hline Slovnaft & 6.8 & 6.5 & 6.7 \\
\hline Istrochem & 10.5 & 12.1 & 9.8 \\
\hline Mlynská dolina & 6.2 & 8.7 & 8.6 \\
\hline Rača & 6.1 & 6.4 & 6.3 \\
\hline Petržalka & 7.6 & 7.3 & 7.8 \\
\hline Control & 3.2 & 3.4 & 3.1 \\
\hline
\end{tabular}

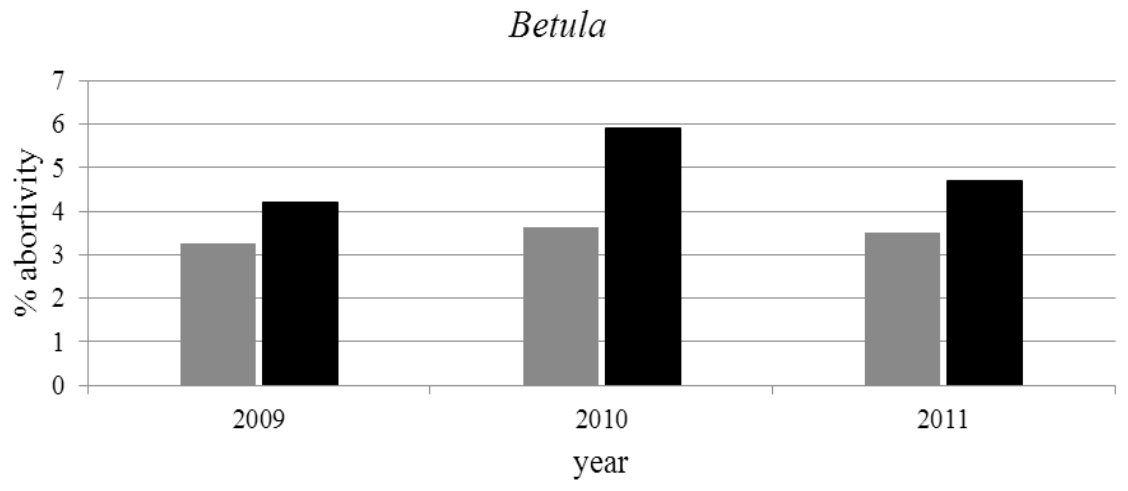

w pollen trap samples $\quad \boldsymbol{\square}$ anther samples

Fig. 6. Comparison abortivity birch pollen measured in pollen trap samples and anther samples in the years 20092011 at the Department of Botany.

city areas fluctuated, ranging from 1.7 to 2.9 . A similar situation was found in the abortivity of Pinus sylvestris L., where the highest induction factor values were measured at Istrochem and the lowest at Rača. 
City incinerator
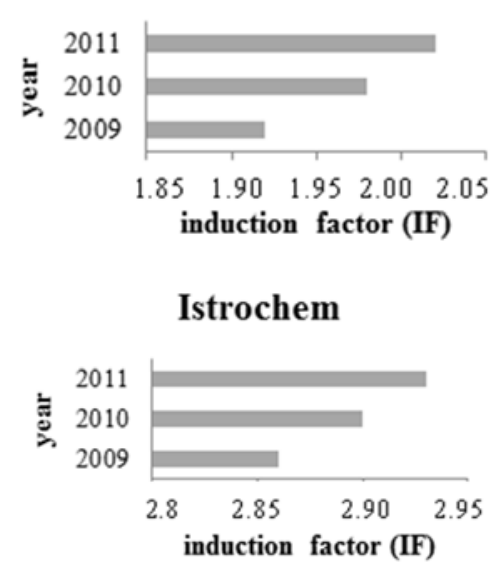

Devínska Nová Ves

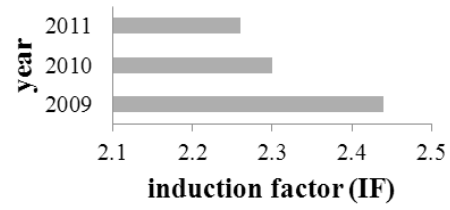

Slovnaft

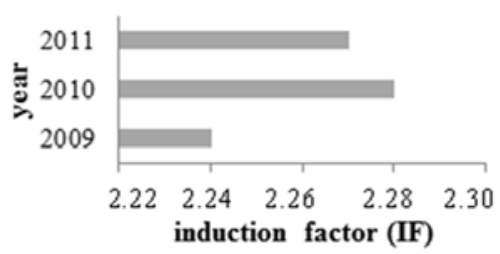

Rača

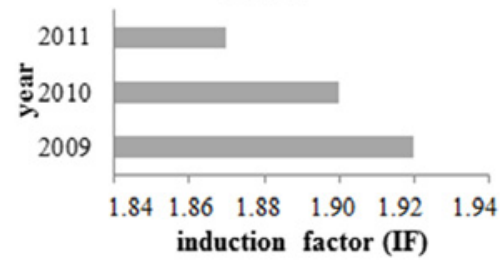

Petržalka

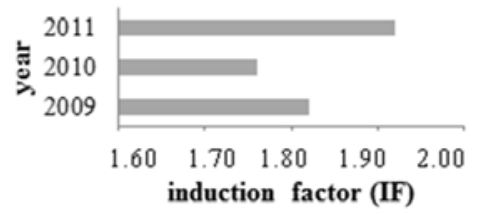

Fig. 7. Induction factor of ecogenotoxicity at sampling sites in Bratislava.

\section{Discussion}

With the exception of the 2007, the annual amounts of pollen grains in the atmosphere of Bratislava were significantly higher at the U.V.Z. station than at D.B station in the monitored years. During the five year experimental period, 287,959 pollen grains were recorded at the U.V.Z. station; 149,166 more than at D.B. The highest number of 74, 806 was recorded in 2011 at the U.V.Z. station and the 14,475 minimum in 2008 at D.B. Pollen grains were recorded from 32 higher plant taxa, consisting of 21 trees and shrubs and 11 herbaceous species. Pollen produced from trees and shrubs comprised $70 \%$ of the total at the U.V.Z. station, and the remaining 30\% came from herbal allergens. At the D.B. station, pollen grains from trees and shrubs made up $64 \%$ of the total, with the other $36 \%$ emanating from herbs. The higher levels of tree pollen are due to trees generally producing more pollen than herbs and also because species diversity of trees in the vicinity of the two monitoring stations is greater than than the diversity of herbs. On average, the most abundant pollen grains in the atmosphere of Bratislava at both stations in the first four years of the study period were from; the Urticaceae family (17.61\%), followed by the genus Betula (15.05\%), Taxaceae, Cupressaceae 
(9.12\%), Pinaceae (8.15\%), Populus (7.52\%), Poaceae (6.05\%) and Ambrosia (5.92\%). In 2011, this sequence varied greatly from that reported by Ščevková et al. (2010), mainly due to the high pollen production of the Urticaceae family, rather than an increase in the abundance produced by the genus Betula.

The highest annual tree pollen totals were observed in the genus Betula, where several authors reported a two year alternating period of high and low pollen production (Nilsson, Persson, 1981; Atkinson, Larsson, 1990; Ščevková et al., 2010). Although this was confirmed by our observations, our 5 year experimental period is too short to postulate a definitive argument.

The plants with the longest pollen season,,were species of the Urticaceae family with an annual average of 125 days. This family has two species in Bratislava: Urtica dioica and $\mathrm{Pa}$ rietaria officinalis, and these species recorded the most abundant pollen of all herbaceous species examined in Bratislava.

Data from the U.V.Z. station can be compared with data measured by Zlinská (1996) in 1994-1995. This was the first monitoring of pollen grains in the atmosphere of Bratislava, garnered from a volumetric pollen trap in the north-eastern part of the city close to the $\mathrm{U}$. V.Z. station. Her data suggests the greatest abundance of Urticaceae, Poaceae and Artemisia pollen in these two monitored years. Compared to our data, the abundance of Betula and Taxaceae-Cupressaceae pollen was surprisingly low, while the quantity of pollen of the genus Rumex in 1994 and Plantago in 1995 was significantly higher than our measured data. Zlinská (1996) lists August as the month with the highest totals of pollen grains during these monitored years. In contradistinction, our highest totals of pollen grains occurred each April, and this agrees with Ščevková et al (2010).

The differences in the quantity of pollen grains between the two pollen stations in Bratislava during the same time period may be due to several factors. One of these is certainly the composition of the close vegetation and built-up area, because the pollen traps were placed in different biotopes in the city. No phyto-geographic research was performed in the north-western part of the city, where the D.B. monitoring station is situated. In the city area of Bratislava-Ostredky, where the U.V.Z. station is situated, a survey of allergenic higher plant species was carried out by Bartková (2000). The allergenic potential of this city area was evaluated based on both quantitative and qualitative analysis. A medium to high allergenic potential was detected in 11 of the total 18 map squares, and 184 plant species producing allergenic pollen were detected.

Another factor influencing the differences in the quantity of pollen grains in the atmosphere is the difference in microclimatic conditions at the individual stations. Data from the Slovak Hydro-meteorological Institute (SHMÚ) suggests that precipitation was higher in the proximity of the D.B. station compared to the U.V.Z. station in each monitored year, with a difference of $156 \mathrm{~mm}$ per year. The temperature was higher at the U.V.Z. station, so this combined higher temperature and lower precipitation could have influenced the higher values of pollen grains measured at the U.V.Z. station.

The differences in pollen quantity between the two stations may also have been due to the two different evaluation methods used. Cariñanos et al. (2000) compared the two methods used in our study, and found that the four longitudinal transect method used at the U.V.Z. 
station yielded slightly higher results of daily pollen concentration than the 12-traverse transect methodology at the D.B. station. Therefore, this may have have been one reason for the differences recorded at these stations. It is also necessary to consider human factors which may have significantly influenced the final values of the measured pollen grains. Different researchers worked with Pollen Information Service (PIS) at Botany in 2008 to those who evaluated the pollen spectrum at the U.V.Z. station from its commencement in 2007. Therefore individual interpretation of samples and results by different researchers remains very important.

When our results are compared with the unpublished data of Mičieta and Chrenová in 2003-2004, it is clear that the abundance of abortive birch pollen caught in our pollen trap did not change significantly over the five years research period, while their data registered $3.5-4.3 \%$ of the total birch pollen. The highest abortivity of birch pollen grains taken directly from the anthers of birch catkins was recorded at 5.9\% in 2010 and the lowest was $4.2 \%$ in 2009 , and these values correspond to the pollen trap data. Each value is approximately $1 \%$ higher than the values from the pollen trap, except in 2010 when it was over $2 \%$ higher. These differences are not significant; therefore birch appears a suitable indicator of ecogenotoxicity in Bratislava, from both measuring the abortive pollen in the trap and measuring it directly in anthers. The monitoring abortivity of the pollen grains caught in the pollen traps serves as a supplementary method for determining ecogenotoxicity in the atmosphere. The procedure involved is simple, suitable for long-term observation and also for determining acute pollution (Mičieta, 2010). It provides precise indication parameters in specific regions. However, future research is needed to completely verify this methodology.

The genus Pinus sylvestris L., was utilized to compare and evaluate ecogenotoxicity and mutagenity in the chosen Bratislavan localities, to verify the effectiveness of the test in the different city areas and to indicate effective use of urban vegetation. The results highlighted the increased ecogenotoxicity in all studied localities, thus corresponding with the data of Mičieta et al. (2008), who also reported the highest abortivity of this species in the proximity of Istrochem. The success of the genus Pinus in phytoindication of pollution in biological systems was therefore proven, and the induction index enables regular monitoring of the air in Bratislava.

\section{Conclusion}

In this study, we compared the results of the aeropalynological research of two independent pollen stations (U.V.Z. and D.B.), localized in different parts of Bratislava during the five year period of 2007-2011. The annual total pollen was considerably higher at the U.V.Z. station each year except for 2007. The five-year total pollen was twice as high at the U.V.Z. station than at D.B. The Urticaceae family accounted for the highest amount of pollen, and the month of April had the highest yield. In addition, Urticaceae family species also had the longest pollen season of all studied taxa.

Observed differences may be due to the following factors,or to a combination of them; (1) the considerably different habitats in the proximity of the stations (2) different microclimatic conditions, (3) the different evaluation methods, and (4) the human factor, due to 
individual researcher's interpretation of samples and results. It is evident from this study that increased density of monitoring stations in a region will provide more accurate data concerning the pollen in the atmosphere, and therfore enable more effective prevention of pollen allergies in these areas.

The methods used for evaluation of the abortivity of airborne pollen are operationally simple and financially accessible, suitable for long-term monitoring and also for emergencies such as accidents and acute cases of air and environmental pollution. They provide precise indicative parameters which signal critical changes in the environment with sufficient speed and accuracy for practical measures to be implemented to minimize negative environmental impacts, especially where genotoxic danger is involved., Their reliability also enables rapid evaluation of perspectives for biota in the critical area. The employed methods enable monitoring of ecogenotoxicity in the air, soil and water in an area's actual ecological and environmental complex. Moreover, results obtained by this methodology can be extrapolated to quickly assess human risk factors (Mičieta et al., 2003).

Acknowledgements

The study was supported by VEGA grant No. 1/0380/13.68/10 and 2/0041/13.

\section{References}

Atkinson, H. \& Larsson K.A. (1990). A 10 year record of the arboreal pollen in Stockholm, Sweden. Grana, 29, 229-237. DOI:10.1080/00173139009427756.

Bartková, J. (2000). Qualitative and quantitative analysis of phytoalergens in the Bratislava-Ostredky area (in Slovak). Ms. Depon in Katedra ekosozológie a fyziotaktiky, Prírodovedecká fakulta Univerzity Komenského in Bratislava.

Bromberg, S. M. (1990). Identifying ecological indicators : an enviromental monitoring and assessment program. Journal of Air Pollution Control Association, 40, 976-978. DOI:10.1080/10473289.1990.10466748.

Cariñanos, P., Emberlin, J., Galán, C. \& Domingues-Vilches E. (2000). Comparison of two pollen counting methods of slides from a Hirst type volumetric trap. Aerobiologia, 16, 339-346. DOI:10.1023/A:1026577406912.

D’Amato, G., Cecchi, L., Bonini, S., Nunes, C., Annesi-Maesano, I. \& Behrendt H. (2007). Allergenic pollen and pollen allergy in Europe. Allergy, 62, 976-990. DOI:10.1111/j.1398-9995.2007.01393.x.

Daubnerová, A. (1999). Qualitative and quantitative analysis of phytoalergens in the Bratislava-Štrkovec area (in Slovak). Ms. Depon in Katedra ekosozológie a fyziotaktiky, Prírodovedecká fakulta Univerzity Komenského in Bratislava.

Drábová-Kochjarová, J. (1990). Synanthropic flora of suburb settlements in Bratislava-Petržalka region and some elements as present and potential sources of pollen allergens. Acta Facultatis Rerum Naturalium Universitatis Comenianae Botanica, 37, 53-63.

Eliáš, P. (1985). The flora of a river port in Bratislava (in Slovak). Zprávy České Botanické Společnosti, 20, $227-228$.

Eliáš, P. (1989): About the occurence of two phytocenoses at the Devín castle (western Slovakia) (in Slovak). Bulletin Slovenskej Botanickej Spoločnosti, Bratislava, 11, 10-13.

Erdtman, G. (1969). Handbook of palynology. Copenhagen: Munksgaard.

Fassatiová, O. (1979). Moulds and fibrous fungi in technical microbiology (in Slovak). Praha: SNTL.

Feráková, V. (1996). Supplements and corrections to the Red list of higher plants in the flora of Bratislava (in Slovak). Bulletin Slovenskej Botanickej Spoločnosti, 18, 148-153.

Feráková, V. (Ed.) (1997). The flora, geology and paleontology of Devinska Kobyla (in Slovak). Bratislava: Litera. 
Hrubiško, M. (1996). Hypersensitivity to pollen of trees, grasses and weeds in Bratislava (in Slovak). Dissertation thesis. Lekárska fakulta, Univerzita Komenského, Bratislava.

Jarolímek, I. (1985). Syntaxonomical overview of ruderal plant communities of Bratislava (in Slovak). Biológia, 40, 489-496.

Jarolímek, I. (1994). Characteristics of built-up area zonation in Bratislava with emphasis on the ruderal plant communities and their habitats (in Slovak). Zpr. Čes. Bot. Společ., 29, 47-55.

Jurko, A. (1958). The soil-ecological conditions and forest cenoses of the Danube plain (in Slovak). Bratislava: SAV.

Michalko, J., Berta J. Magic D. (1986). Geobotanical map of ČSSR. Text part SSR (in Slovak). Bratislava: Veda.

Mičieta, K. \& Murín G. (1996). Microspore analysis for genotoxicity of polluted environment. Environ. Exp. Bot., 36, 21-27. DOI:10.1016/0098-8472(95)00050-X.

Mičieta, K. \& Murín G. (1997). Wild plant species in practical use for bioindication of polluted environment. Ekológia (Bratislava), 16, 193-202.

Mičieta, K. \& Murín G. (1998). Three species of genus Pinus suitable as bioindicators of polluted environment. Water, Air, Soil Pollut., 104, 413-422. DOI:10.1023/A:1004984121831.

Mičieta, K. \& Kunová K. (2000). Phytoindication of genotoxic deterioration of polluted environment. Biologia (Bratislava), 55(Suppl.8), 75-79.

Mičieta, K., Murín, G., Kunová, K., Halašová, E. \& Bukovská E. (2003). Monitoring of genotoxic risk in industrial areas with an example Ružomberok papermill and factory. In W.A. Jendrychowski, F.P. Perera \& U. Maugeri (Eds.), Molecular epidemiology in preventive medicine (pp. 273-280). Krakow: International Center for Studies and Research in Biomedicine in Luxembourg.

Mičieta, K., Murín, G. \& Dušička J. (2008). Woody plants in indication and monitoring of ecogenotoxicity in urban agglomeration. Environmental changes and biological assessment IV. Universitas Ostraviensis, 70_74.

Mičieta, K. (2010). Palynological analysis in the evaluation of quality of the environment (in Slovak). Acta Environmentalica Universitatis Comenianae (Bratislava), 18, 104-111.

Mišík, M., Mičieta, K., Solenská, M., Mišíková, K., Pisarčíková, H. \& Knasmüller S. (2007). In situ biomonitoring of the genotoxic effects of mixed industrial emissions using the Tradescantia micronucleus and pollen abortion tests with wild life plants: Demonstration of the efficiency of emission controls in a European city. Environ. Pollut., 145, 459-466. DOI:10.1016/j.envpol.2006.04.026.

Mucina, L. (1981). Relation between ruderal and potential natural vegetation in the case of Great Bratislava (in Slovak). Biológia, 36, 901-905.

Nilsson, S. \& Persson S. (1981). Tree pollen spectra in the Stockholm region (Sweden), 1973-1980. Grana, 20, 179-182. DOI:10.1080/00173138109427661.

Spieksma, F. Th. M., Nolard, N., Frenguelli, G. \& van Moerbeke D. (1996). Pollens de l'air en Europe UCB Secteur Pharmaceutique. Brussel: Braine l'Alleud, UCB Pharma, Ltd.

Ščevková, J., Dušička, J., Chrenová, J. \& Mičieta K. (2010). Annual pollen spectrum variations in the air of Bratislava (Slovakia): years 2002-2009. Aerobiologia, 26, 277-287. DOI:10.1007/s10453-010-9163-1.

Winkler, H., Ostrowski, R. \& Wilhelm M. (2001). Pollenbestimmungsbuch der Stiftung Deutscher Polleninformationsdienst. Paderborn: Takt Verlag.

Zlinská, J. (1996). The first results of pollen allergens monitoring in the atmosphere of Bratislava (in Slovak). Seminár Enviro Nitra, 224-226. 